\title{
Managing atopic dermatitis with systemic therapies in adults and adolescents. An Australian/New Zealand narrative.
}

Rademaker M, Agnew K, Andrews M, Baker C, Foley P, Gebauer K, Gupta M, Rubel D, Somerville C, Sullivan J, Wong, L-C

Address for correspondence: Hon. Associate Professor Marius Rademaker, Waikato Clinical School, Auckland University Medical School, Hamilton, New Zealand

Tel: +6478381035

Email: Rademaker@xtra.co.nz

- Word Count: 6836

- Tables: 1, but with a separate list of bullet points

- Figures: 0

- Key words: atopic dermatitis, atopic eczema, second line therapy, systemic treatment, corticosteroids, methotrexate, ciclosporin, azathioprine, mycophenolate, biologic therapies, small molecules

- Short title: Systemic agents for atopic dermatitis

Acknowledgments: We are very grateful to AbbVie Pty Ltd (Australia) for an unrestricted educational grant. They had no influence in the subject matter, discussion or writing up. We are grateful for Tony James, independent medical writer for taking notes during the meeting. He was not otherwise involved in the preparation of this manuscript.

Authorship:

- Design, literature search, discussion, conclusions, final version of manuscript - all authors

- Manuscript preparation - MR

- Final manuscript - all authors

Conflicts of Interest:

This is the author manuscript accepted for publication and has undergone full peer review but has not been through the copyediting, typesetting, pagination and proofreading process, which may lead to differences between this version and the Version of Record. Please cite this article as doi: 10.1111/AJD.13141

This article is protected by copyright. All rights reserved 


\begin{tabular}{|l|l|}
\hline Rademaker & None \\
\hline Agnew & None \\
\hline Andrews & None \\
\hline Baker & Clinical Investigator, speaker and/or advisory board: AbbVie, Janssen, \\
& Novartis, Pfizer \\
\hline Foley & Consultant, investigator, speaker and/or advisor for and/or received travel \\
& $\begin{array}{l}\text { grants: 3M/iNova/Valeant, Abbott/AbbVie, Amgen, Biogen Idec, BMS, } \\
\text { Boehringer Ingelheim, Celgene, Celtaxsys, Cutanea, Dermira, Eli Lilly, }\end{array}$ \\
& Galderma, GSK/Stiefel, Janssen, LEO/Peplin, Novartis, Regeneron, Sanofi \\
& Genzyme, Schering-Plough/MSD, Sun Pharma, UCB, and Wyeth/Pfizer \\
\hline Gebauer & Clinical investigator and/or Advisory Board: AbbVie, Celgene, Janseen, Eli \\
& Lilly \\
\hline Gupta & None \\
\hline Rubel & Clinical Investigator and/or Advisory Board: AbbVie, Amgen, Boehringer- \\
& Ingelheim, Celgene, Eli Lilly, Janssen, Novartis, Sun Pharma \\
\hline Somerville & $?$ \\
\hline Sullivan & None \\
\hline Wong & Advisory Board: Pfizer \\
\hline
\end{tabular}

Name/Degree/Affiliation

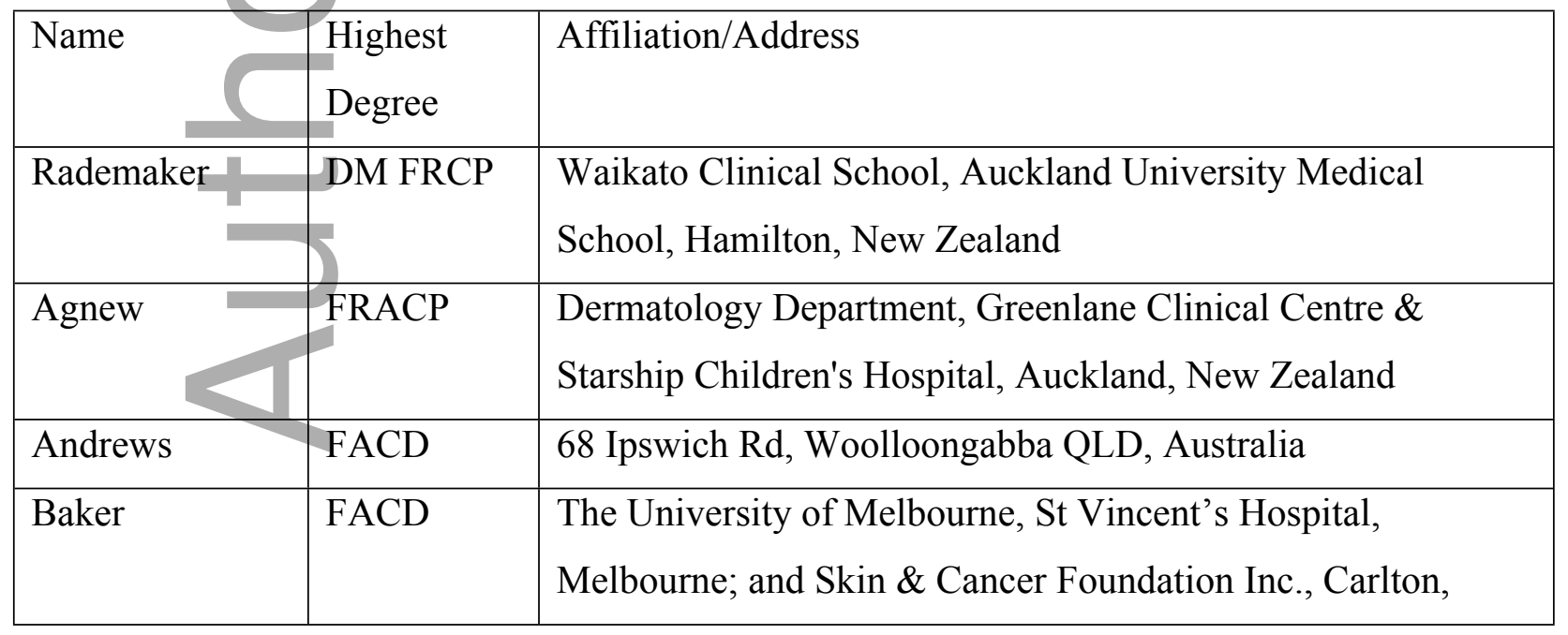

This article is protected by copyright. All rights reserved 


\begin{tabular}{|l|l|l|}
\hline Foley & MD FACD & $\begin{array}{l}\text { The University of Melbourne, St Vincent's Hospital, } \\
\text { Melbourne; and Fitzroy and Probity Medical Research, Skin } \\
\text { \& Cancer Foundation Inc., Carlton, VIC, Australia }\end{array}$ \\
\hline Gebauer & FACD & $\begin{array}{l}\text { University of Western Australia, Perth; and Probity Medical } \\
\text { Research, Freemantle, WA, Australia }\end{array}$ \\
\hline Goh & FACD & $\begin{array}{l}\text { St Vincent's Hospital, Melbourne; and Skin \& Cancer } \\
\text { Foundation Inc., Carlton, VIC, Australia }\end{array}$ \\
\hline Gupta & FACD & $\begin{array}{l}\text { Department of Dermatology, Liverpool Hospital, Sydney; The } \\
\text { Skin Hospital, Darlinghurst; and University of New South } \\
\text { Wales, Sydney, NSW, Australia }\end{array}$ \\
\hline Rubel & FACD & $\begin{array}{l}\text { Woden Dermatology, Phillip, ACT; and Australian National } \\
\text { University, ACT, Australia }\end{array}$ \\
\hline Somerville & FACD & Kingsway Dermatology, Miranda NSW, Australia \\
\hline Sullivan & FACD & $\begin{array}{l}\text { The Children's Hospital at Westmead, Sydney, NSW, } \\
\text { Australia }\end{array}$ \\
\hline Wong & &
\end{tabular}

This article is protected by copyright. All rights reserved 
PROF. MARIUS RADEMAKER (Orcid ID : 0000-0003-3393-6748)

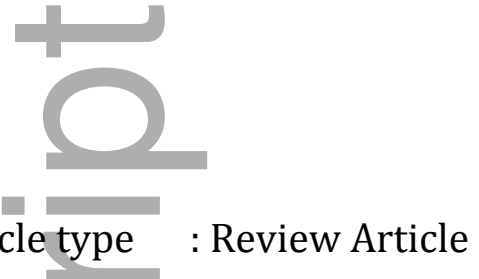

Article type : Review Article

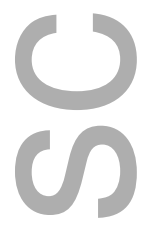

Managing atopic dermatitis with systemic therapies in adults and adolescents. An Australian/New Zealand narrative.

Abstract

With the rapid development of new, targeted therapies for the treatment of moderate/severe atopic dermatitis, it is opportune to review the available conventional systemic agents. We assess the published evidence for systemic therapies for atopic dermatitis, and amalgamate this with real world experience. Discussions are centred on when systemic therapy should be considered, which $\operatorname{drug}(s)$, what dose, how to sequence or combine these therapies, how long they should be continued for, and what is considered success.

\section{Introduction}

There are numerous atopic dermatitis guidelines, reviews and expert opinions, yet few provide specific, practical advice, on the use of systemic therapies for patients with severe disease.(1-5) This is partly due to the paucity of well designed clinical trials of systemic agents for severe atopic dermatitis, as well as that most systemic agents in current use are 'off-label'. With the recent development of monoclonal antibodies and small molecules targeting specific cytokines, we may be entering a new era of therapy for severe atopic dermatitis. However, these new therapies are likely to be significantly more expensive, so it is prudent that the current systemic This article is protected by copyright. All rights reserved 
therapies have been considered and used appropriately before switching. We review the published evidence for current systemic therapies of atopic dermatitis, and amalgamate this with real world experience.

\section{Methods}

This narrative is based on an extensive literature review (search terms: alitretinoin, apremilast, azathioprine, baricitinib, ciclosporin, corticosteroids, dupilumab, interferon, IVIG, JAK inhibitors, infliximab, lebrikizumab, leflunomide, methotrexate, mepolizumab, monoclonal antibodies, montelukast, mycophenolate mofetil, nemolizumab, omalizumab, phosphodiesterase inhibitors, prebiotics, prednisone, prednisolone, probiotics, systemic antibiotics, systemic therapy, retinoids, rituximab, tacrolimus, thymic stromal lymphopoietin, tofacitinib, tralokinumab, triamcinolone, upadacitinib, ustekinumab, vitamin D, vitamin $\mathrm{E}$ and atopic dermatitis or its synonyms; all languages, all types of articles). We excluded phototherapy, immunotherapy and antihistamines from the review. Each therapy was given a discussion lead who synthesised the available evidence, which was presented at a daylong meeting. Group members were all experienced medical dermatologists from the main centres of Australia and New Zealand.

Discussions centred on when systemic therapy should be considered, which drug(s), dosing, sequencing, combination, duration, and what was considered success, based around 3 clinical scenarios (Supplementary material).

\section{Results}

The results are discussed as general principles followed by more detailed, specific commentary on the individual systemic agents. There was general agreement by the group as to the broader principles of when to start treatment, duration of treatment, and what determined success, with variation in which was the first choice systemic therapy and the sequencing. There was more variation within the group as to the type and frequency of monitoring for adverse effects of therapy.

\section{Please insert Bullet points where best fits}

This article is protected by copyright. All rights reserved 


\section{When to start systemic therapy}

The decision to start a systemic therapy for the management of atopic dermatitis is complex and should take into account severity of the patient's symptoms, the lack of response to appropriately prescribed and used topical therapies (including phototherapy), and patient co-morbidities. The three main barriers to using systemic agents are the prescriber's discomfort in using these therapies, the direct and indirect associated costs (pharmaceuticals, monitoring, medical fees, patient time, etc.) and the patient's perspective of the benefit/risk of the therapy. ${ }^{(6-8)}$

A number of criteria have been proposed including specific levels of clinical disease activity (e.g. SCORAD - SCOring Atopic Dermatitis, EASI - Eczema Area and Severity Index, SASSAD - Six Area, Six Sign Atopic Dermatitis), patient quality of life scores (e.g. DLQI - Dermatology Life Quality Index, EQ-5D - EuroQol 5 Dimension), the amount of potent topical corticosteroid use, the number of relapses, number of hospital admissions, etc., but as each patient's individual circumstances vary, it is difficult to develop practical recommendations. ${ }^{(9)}$

The group felt that systemic therapy should be offered to all patients with atopic dermatitis that was significantly affecting their quality of life. This shared decisionmaking should include discussion regarding:

- Specific treatment goals and expectations

- The strategy to reach these goals

- The therapeutic options and their potential adverse effects

- The added risks of any comorbidities

- Practical matters including socioeconomic considerations

\section{Individual Systemic agents}

A number of studies have surveyed systemic agent use in severe atopic dermatitis. Armstrong reviewed systemic immunomodulator therapy in 4204 American patients (67.5\% female, mean age, 50.9 years) with atopic dermatitis: $51.3 \%$ received methotrexate, $17.3 \%$ mycophenolate mofetil, $16.9 \%$ ciclosporin, and This article is protected by copyright. All rights reserved 
14.5\% azathioprine. ${ }^{(7,8)}$ During the 1-year follow-up, 36.3\% required dose escalation, while $2.8 \%$ of patients switched and $7.6 \%$ required additional therapies. The mean time to discontinuation was 88.1 days. Systemic corticosteroids were used in $72.3 \%$ of patients. Only $2.4 \%$ of patients were treated with phototherapy.

In a survey of 133 paediatric dermatologists, ${ }^{(10)}$ the preferred first-line systemic therapy was ciclosporin (45.2\%), methotrexate (29.6\%), and mycophenolate $(13.0 \%)$. The most commonly used second-line agents were methotrexate (31.3\%) and mycophenolate (30.4\%); azathioprine was the most commonly cited third-line agent. The main factors that discouraged use of systemic agents were side-effect profiles (82.6\%) and perceived risks of long-term toxicity (81.7\%).

The group expressed two approaches to starting systemic therapy: 1) combination therapy with 6-10 weeks of a faster acting agent (in order of the group's preference: ciclosporin, systemic corticosteroids, phototherapy or admission for wet wraps) as a bridging treatment to a second, slower acting maintenance therapy (e.g. methotrexate, ciclosporin, azathioprine, mycophenolate); or 2) simply starting a slower acting therapy (in order of the groups preference: methotrexate, ciclosporin, azathioprine, mycophenolate). The rationale for a 6-10 week faster acting therapy included giving the patient 'normal' skin, often for the first time in many years, increasing the patients' confidence in subsequent systemic therapy, and ultimately a better response to the slower acting therapy.

\section{Corticosteroids (oral, intramuscular, intravenous)}

Despite the known effectiveness of systemic corticosteroids in controlling the symptoms of atopic dermatitis, most guidelines, reviews and expert commentaries discourage their use based on the known adverse effect profile and the frequent relapse/rebound on stopping.(11) The general recommendations are that they should be limited to no more than two weeks for the management of acute flares, or as a bridging treatment to another systemic agent.

Corticosteroids target gene transcription resulting in activation of antiinflammatory genes as well as suppression of pro-inflammatory genes. Potency is This article is protected by copyright. All rights reserved 
determined by affinity for the intracellular glucocorticoid receptor and duration of action. Whilst corticosteroids are immunomodulatory, above $20 \mathrm{mg} /$ day prednisone equivalent may also have immunosuppressive effects. Corticosteroid insensitivity/resistance is not well recognised by dermatologists, but occurs in up to $30 \%$ of patients with chronic asthma or rheumatoid arthritis. ${ }^{(12)}$

Whilst there are no quality studies of oral corticosteroid use for the management of atopic dermatitis, ${ }^{(13-17)}$ they are widely prescribed, with a high satisfaction rating by patients. (7.18) Similarly the studies of intramuscular triamcinolone, $(19,20)$ intravenous methylprednisone (21) or sub cutaneous ACTH depot ${ }^{(22,23)}$ are all of low quality, although they do indicate short-term response. A 4-week study in 26 children with severe atopic dermatitis compared combined oral and nasal beclomethasone dipropionate $(1200 \mu \mathrm{g} /$ day $)$ to placebo.(14) It identified a $22 \%$ decrease in mean severity, lower parent-assessed overall disease activity and greater preference for beclomethasone. In another study beclomethasone dipropionate $600 \mu \mathrm{g} 3$ times daily for 4 weeks followed by 800-1800 $\mu \mathrm{g}$ daily for 6 weeks improved disease activity in 14 of 15 children with severe atopic dermatitis, but the disease relapsed in 4 children once the dose was tapered.(15) Flunisolide $640-1200 \mu \mathrm{g} /$ day for 2 weeks reduced clinical severity scores by $49 \%$ compared to placebo after 2 weeks in 20 children with atopic dermatitis.(16) Intravenous methylprednisolone $20 \mathrm{mg} / \mathrm{kg} / \mathrm{d}$ for 3 consecutive days resulted in immediate improvement of skin lesions and pruritus in 5 of 7 children.(21)

In a comparison of prednisolone $(0.5-0.8 \mathrm{mg} / \mathrm{kg} /$ day, tapered within 2 weeks $)$ with 6 weeks of ciclosporin (2.7-4 mg/kg/day), in adults with severe atopic dermatitis, only 1 of 27 patients treated with prednisolone achieved sustainable remission as opposed to 6 of 17 treated with ciclosporin.(17)

Oral dosing of glucocorticoids is best once daily, early in the morning, to minimise nocturnal sleep disruption. Alternate day dosing has been recommended for longerterm maintenance therapy, on the hypothesis that it reduces adverse effects. 
Adverse events of systemic corticosteroids include hypertension, glucose intolerance, gastritis, weight gain, decreased bone density, adrenal suppression, and emotional lability. A systematic review of adrenal insufficiency (cortisol level $\leq 500$ $\mathrm{mol} / \mathrm{L}$ ) after glucocorticoid included only a few patients with atopic dermatitis among 3753 participants. (24) Meta-analysis showed a significant increase in absolute risk with medium ( 1 month to 1 year) and long-term (>1 year) use, as well as with medium- and high-dose corticosteroids. Approximately half the patients had resolution of adrenal insufficiency upon retesting at 28 days. Tapering of corticosteroids was deemed unnecessary with courses lasting less than 1 week, but a 7-14 day or 15-30 day taper until a physiologic dose $\left(10 \mathrm{mg} / \mathrm{m}^{2} /\right.$ day $)$ was recommended for courses of 2-3 weeks or $\geq 4$ weeks, respectively. Oral corticosteroids are generally considered safe for use in pregnancy and breastfeeding, $(25,26)$ although it has been recommended to delay breastfeeding for 3 to 4 hours after ingestion of prednisone to minimise exposure to the infant.

Some members of the group preferred systemic corticosteroids over ciclosporin as the bridging treatment to a longer term maintenance therapy, the dose used depending on the available tablet size (e.g. prednisone $20 \mathrm{mg}$ tablet: $40 \mathrm{mg} / \mathrm{mane}$ for 1 week, $20 \mathrm{mg}$ mane for 2 weeks, $10 \mathrm{mg}$ mane for 3 weeks with a possible extension of $5 \mathrm{mg} / \mathrm{mane}$ for 4 weeks; or prednisolone $25 \mathrm{mg}$ tablet: $50 \mathrm{mg} 1$ week, $25 \mathrm{mg} 2$ weeks, $12.5 \mathrm{mg} 3$ weeks; or i.m. triamcinolone $40 \mathrm{mg}$ stat, repeated in one month if needed). The rationale, as well as providing patients with a symptom-free 'holiday', demonstrating to patients and families that 'normal' skin is possible, was to assess steroid responsiveness to assist in prospectively determining the value of second-line therapy. There was variation on the recommended monitoring from none (unless clinically indicated), to baseline osteoporosis investigation; there was also variation in co-prescribing, from none (unless symptomatic) to a proton pump inhibitor and osteoporosis prophylaxis.

Several members also used long term ( $>1$ year), low dose prednisone/ prednisolone (5-10 mg/day) for the management of late onset atopic dermatitis in the elderly ( $>75$ years) patient with significant itch affecting their quality of life.(13)

This article is protected by copyright. All rights reserved 


\section{Methotrexate}

Low-dose methotrexate $(<0.4 \mathrm{mg} / \mathrm{kg}$ per week) is anti-inflammatory, rather than immunosuppressive, with a long history of use in dermatology. (27) Although generally of poor to moderate quality, multiple small studies of methotrexate show a $40-70 \%$ improvement in atopic dermatitis disease activity scores. ${ }^{28-33)}$ It is as effective as ciclosporin and azathioprine ${ }^{(31)}$ in the short term, has prolonged drug survival and post-drug survival compared to ciclosporin,(33) and is generally well tolerated.

An open-label dose-ranging study in 12 adults with moderate to severe atopic dermatitis initiated treatment at $10 \mathrm{mg} /$ week, which was increased by $2.5 \mathrm{mg} /$ week until a response or until toxicity occurred.(29) The mean improvement in the primary outcome of SASSAD score was 52\%, accompanied by significant improvements in BSA, DLQI, itch and loss of sleep scores. One patient withdrew because of side effects. The majority of patients had persistent improvement 12 weeks after ceasing methotrexate.

Two randomised controlled trials have investigated methotrexate in atopic dermatitis. The first assigned 42 patients to methotrexate $10-22.5 \mathrm{mg} /$ week or azathioprine $1.5-2.5 \mathrm{mg} / \mathrm{kg} /$ day for 12 weeks;(30) at week 12 , patients in the methotrexate group had a mean relative reduction in SCORAD of $42 \%$ compared to $39 \%$ in the azathioprine group $(\mathrm{P}=0.52)$. Proportions of patients achieving at least mild disease and reductions on impact of quality of life and were similar. No statistically significant differences were found in the number and severity of adverse events but abnormalities in blood count were more common in the azathioprine group. Long-term follow-up after 2 years suggested sustained benefits from 12 weeks' treatment with either drug.(31) In an intention-to-treat analysis there was a $63 \%$ relative reduction in SCORAD from baseline in the methotrexate group and $53 \%$ reduction in the azathioprine group, with no significant difference between them. 
A randomised, multicentre trial, evaluated the efficacy and safety of methotrexate (15 mg/week) versus ciclosporin ( $2.5 \mathrm{mg} / \mathrm{kg} /$ day) for 8 weeks in 97 patients with moderate-to-severe atopic dermatitis. ${ }^{(32)}$ When SCORAD 50, the primary endpoint, was not achieved at week 8, methotrexate was increased to $25 \mathrm{mg} /$ week and ciclosporin to $5 \mathrm{mg} / \mathrm{kg} /$ day for a further 16 weeks. Methotrexate was inferior to ciclosporin at week 8, but similar by week 20. Methotrexate demonstrated a better safety profile than ciclosporin.

Drug survival (time on the drug) and post-drug survival (time after ceasing the medication to commencing another one), was used to compare 25 children and adults treated with ciclosporin (mean maximum dose $3.6 \mathrm{mg} / \mathrm{kg} /$ day) to 31 treated with methotrexate (mean maximum dose $16 \mathrm{mg} /$ week).(33) Mean drug survival was 8 months for ciclosporin and 23 months for methotrexate, and median post-drug survival was 2 months and 12 months respectively. Both differences were statistically significant. Controlled disease was the most common reason for discontinuing methotrexate, while primary failure was the most common reason for ceasing ciclosporin. In a larger drug survival report of 89 patients, $60 \%$ of patients remained on methotrexate (reasons for stopping: ineffective -15\%, adverse effects $25 \%) \cdot(34)$

The adverse effects of methotrexate, recommended monitoring, advice on vaccines and pregnancy concerns have previously been reviewed by the group.(27) For pretreatment, consider testing full blood count (FBC), liver and renal function, nonfasting lipids, hepatitis serology, HbA1c and glucose. Optional investigations in atrisk groups include an HIV test, an interferon-gamma release assay (e.g. QuantiFERON-TB Gold) and a chest X-ray. In patients without complications, repeat the FBC at 2-4 weeks, then every 3-6 months and the liver/renal function test at 3 months and then every 6 months. Methotrexate is a teratogen.

The group favoured methotrexate (15-25 mg/week) as both a first (with or without bridging therapy) and second line therapy. They were also happy to consider combination with prednis(lo)one, ${ }^{(35)}$ ciclosporin, azathioprine and mycophenolate, 
but at a slightly reduced dose (10-15 mg/week). Methotrexate is generally well tolerated; this can be improved by subcutaneous administration.(35)

\section{Ciclosporin}

Ciclosporin is one of the few systemic treatments indicated for the treatment of atopic dermatitis. It has a narrow therapeutic index, complicated by variable interpatient and intra-patient bioavailability. A review of systemic treatments for atopic dermatitis identified 14 trials, which consistently found that ciclosporin improved clinical signs of atopic dermatitis in children and adults. ${ }^{(28)}$ In practice, twice daily ciclosporin (3-5 mg/kg/day for 8-12 weeks) is used most commonly for control of acute flares, and as intermittent short courses (8-12 weeks) for continued disease control. ${ }^{(36,37)}$ A significant reduction in disease activity can be expected in 2-6 weeks, and response should be formally assessed at 6-8 weeks. Ciclosporin should be discontinued after 12 weeks if insufficient response. Unfortunately relapse/rebound on stopping ciclosporin occurs frequently. ${ }^{(37)}$ Continuous maintenance for one to two years is sometimes used, but there is concern regards long term adverse effects.

Close monitoring (monthly blood pressure, full blood count, renal and liver function tests) is recommended because of potential adverse effects including infection, nephrotoxicity, hypertension, tremor, hypertrichosis, headache, gingival hyperplasia, and increased risk of skin cancer and lymphoma. ${ }^{38)}$ Dosing is based on ideal body weight. Ciclosporin is a pregnancy category $\mathrm{C}$ drug, with studies showing a slightly higher incidence of low birth weight and prematurity but no increased risk of foetal anomalies.(39) Live vaccines should be avoided. There are a number of potentially significant drug-drug interactions.

The group were divided in their use of ciclosporin: most were happy to use ciclosporin as an alternative to systemic corticosteroids (e.g. as bridging therapy), but were less comfortable in using ciclosporin as a longer term $1^{\text {st }}$ or $2^{\text {nd }}$ line treatment, mostly due to concerns around rebound and toxicity. Some members were comfortable adding ciclosporin to methotrexate, azathioprine or 
mycophenolate for recalcitrant dermatitis, but not with phototherapy, due to increased risk of cutaneous malignancy. ${ }^{(40)}$

\section{Azathioprine}

The use of azathioprine in dermatology is off-label but it is widely prescribed as a steroid-sparing agent. Azathioprine is rapidly absorbed and metabolised but the active metabolite 6-thioguanine accumulates slowly, so maximal efficacy may not be achieved for 3-6 months. Polymorphisms in the enzyme thiopurine methyltransferase (TPMT) influence the efficacy and toxicity of azathioprine; $(2,30,38)$ $11 \%$ of Caucasians have low levels, which increases the risk of neutropenia. The xanthine oxidase inhibitor allopurinol can advantageously switch thiopurine metabolism towards 6-thioguanine in a subgroup of patients with an inadequate response to azathioprine, but should be used with caution to avoid the risk of azathioprine toxicity.

The efficacy of azathioprine in moderate to severe atopic dermatitis despite optimal topical therapy has been assessed in a placebo-controlled trial in 54 patients dosed by TPMT activity. ${ }^{(41)}$ After 12 weeks there was a 37\% improvement in the SASSAD compared to only $20 \%$ in the placebo group (17\% difference; $95 \%$ confidence interval (CI) 4.3-29). A similar study in 37 patients reported a SASSAD reduction of $26 \%$ in azathioprine-treated patients compared to a $3 \%$ reduction in those randomised to placebo $(\mathrm{p}<0.01) .{ }^{(42)}$ Note however, 12 weeks is relatively short for a trial of azathioprine.

Gastrointestinal side effects are the most common dose-limiting feature and can be addressed by reducing the dose, dividing the dose or taking the medication with food. The risk of myelosuppression and hypersensitivity require initial monitoring. Azathioprine hypersensitivity syndrome can develop 1 to 4 weeks after commencing therapy, and is more common than TPMT related neutropenia. Routine blood and liver function tests at baseline and every 2 weeks for 2 months, and then monthly for 4 months has been recommended.(38) Whilst azathioprine has a 
pregnancy risk classification of $\mathrm{D}$, it is generally considered safe. ${ }^{\left({ }^{39)}\right.}$ Live vaccines should be avoided.

The group's clinical experience suggests that an excellent response to azathioprine (1-3 mg/kg/day) can be expected in about one-third of patients after 6 months, with a partial response in another one-third of patients. Because of this delay in response, bridging treatment is usually necessary, and it relegates azathioprine to $2^{\text {nd }}$ or $3^{\text {rd }}$ line treatment choice. As the mode of action is similar to that of mycophenolate, there may be little value in combining these two drugs. Once good control has been established, the dose can slowly be reduced; long-term maintenance may only require daily doses of $25-50 \mathrm{mg}$.

\section{Mycophenolate mofetil}

Mycophenolate modulates the proliferative responses of T- and B-lymphocytes leading to lower levels of immunoglobulins and a decrease in delayed hypersensitivity responses. A number of small studies and case series have reported inconsistent efficacy of off-label use in atopic dermatitis. ${ }^{28,38)}$ In the largest reported study, 55 patients with severe atopic dermatitis were randomised to ciclosporin 3 $\mathrm{mg} / \mathrm{kg}$ or $1440 \mathrm{mg} /$ day enteric-coated mycophenolate.(43) Disease activity assessed by SCORAD after 30 weeks of maintenance therapy was comparable in both study arms and the side effects of both drugs were mild and transient. Disease activity significantly increased in the ciclosporin arm compared to the mycophenolate arm after withdrawal of the study medications.

The typical starting dose of mycophenolate mofetil is $500 \mathrm{mg} /$ day, increasing weekly to 1-2 gm/day. Monitoring is by full blood count, renal and liver function tests after 1 month and then every 3-4 months in otherwise healthy individuals. Dose-dependent gastrointestinal side effects include nausea, diarrhoea, soft stools, anorexia, abdominal cramps, vomiting and peptic ulcer disease. Urinary, infectious and neurological adverse events have been reported but are rarely severe. A number of potential drug interactions need to be considered. Although initially classified as Pregnancy Risk category C, mycophenolate is potentially teratogenic, so 
is contraindicated in pregnancy. ${ }^{(39)}$ Relative contraindications include lactation, peptic ulcer disease, hepatic disease and renal disease. Live vaccines should be avoided.

There was heterogeneity in the group regarding the positioning of mycophenolate with some members using mycophenolate as a $1^{\text {st }}$ line systemic therapy, and others only as an add-on to (or following) ciclosporin or methotrexate.

\section{Systemic antibiotics (anti-Staphylococcus aureus)}

The skin microbiome is emerging as a key element in inflammatory skin conditions including atopic dermatitis. There is a complex symbiotic relationship between microbial communities and tissue, mediated by the innate and the adaptive immune systems-(44) Differences in the skin microbiome between patients with atopic dermatitis and the general population have been identified.(45) They include an increase in Staphylococcus aureus, which is proportional to disease severity, thought to be due to defects in innate immune responses, compromised barrier integrity, and changes in sphingolipids, adhesins and Th2/IL-4 activity. S. aureus colonisation in atopic dermatitis has been associated with increased toxin production and the presence of super antigens. Other changes include a reduced presence of $S$. epidermidis, coagulase-negative staphylococci and cutibacteria. Exacerbation of disease is commonly associated with $S$. aureus infection, which generates exoproteins that enable invasion and dissemination within the skin and also activates the immune system. ${ }^{(46)}$

Systemic and topical antimicrobial therapy reduces $S$. aureus numbers but the change generally does not translate well to clinical benefit. Patients treated with antibiotics quickly become recolonised with the same toxin-secreting organisms, and long-term treatment is not recommended because of the concerns for antibiotic resistance. Colonisation with methicillin-resistance $S$. aureus (MRSA) is a concern. Its prevalence is estimated at $11-34 \%$ in patients with atopic dermatitis who carry the organism compared to $1-3 \%$ of the general population. ${ }^{(47)}$ MRSA increases the risk of developing active infection and of super antigen production.

This article is protected by copyright. All rights reserved 
If antibiotics are to be used for atopic dermatitis, they should be accompanied by active treatment with topical corticosteroids and emollients. In the absence of an exudate or crust, the efficacy of antibiotics is uncertain and the elimination of staphylococci carriage is unlikely. Whilst there is no evidenced based role for prophylactic oral antibiotics in atopic dermatitis, they are commonly used.

The group generally avoided the use of systemic antibiotics in adults, other than for short term (1-2 weeks) control of $S$. aureus infected dermatitis. Longer term courses ( $\geq 3$ months) were occasionally recommended for patient with co-morbidities such as recurrent $S$. aureus boils.

\section{Leflunomide}

Leflunomide is an immune-modulator approved for the treatment of rheumatoid arthritis and psoriatic arthritis. ${ }^{(48)}$ It has been proposed as a novel treatment for atopic dermatitis,(49) but there is very little evidence on its efficacy in the disease and it is rarely considered in clinical practice. It is contraindicated in pregnancy.(39)

\section{Montelukast}

A systematic review of off-label use of montelukast in atopic dermatitis included 11 studies in children and adults. (50) The studies were small in size (the largest included 61 patients) and assessed as being of low quality. Treatment duration ranged from 4 to 20 weeks, at doses of $10 \mathrm{mg} /$ day in adults. Montelukast improved symptoms such as pruritus in four studies; in two studies it improved symptoms similar to the standard regimen of topical corticosteroid and oral antihistamine; and in five studies it had no effects on symptoms. Montelukast was associated with a similar safety profile to placebo, was well tolerated with minimal adverse effects. Montelukast is classified as pregnancy risk category B1; studies in asthma have indicated an increased risk in of preterm birth and maternal complications, but no increased risk of congenital anomalies. ${ }^{(51)}$

\section{Oral tacrolimus}

This article is protected by copyright. All rights reserved 
Tacrolimus, a calcineurin inhibitor with a higher potency than ciclosporin, has a narrow therapeutic index. There is considerable data on topical tacrolimus in atopic dermatitis, but relative little for oral tacrolimus. In an open-label study in 12 patients, 3 weeks of oral monotherapy $(0.08 \mathrm{mg} / \mathrm{kg} /$ day in divided dose $)$, followed by 3 weeks in combination with topical tacrolimus and then 8 weeks of topical therapy, was associated with improvements in EASI, Physician Global Assessment score and pruritus scores. (52) In another open label study, 9 adults (5 female, mean age 42.5 years) were switched from ciclosporin to an extended release formulation of tacrolimus (starting dose $0.15-0.2 \mathrm{mg} / \mathrm{kg} /$ day) for six months. ${ }^{(53)}$ After two weeks, the mean SASSAD decreased from 31.4 to $15.2(\mathrm{p}<0.05)$ and mean BSA from $62 \%$ to $43 \%$ ( $p<0.05)$, which persisted in 7 of the 9 patients. Side effects included nausea, vomiting and diarrhoea, and elevated serum creatinine in one patient. Other reports of its use in atopic dermatitis are limited to small case series. $(54,55)$

\section{Intravenous immunoglobulin (IVIG) and intramuscular immunoglobulin}

Intravenous immunoglobulin, a plasma product pooled from up to 20,000 donors, has been assessed in a randomised placebo-controlled study in 40 children with moderate to severe atopic dermatitis; significant improvement was noted after 3 doses of IVIG ( $2 \mathrm{gm} / \mathrm{kg} /$ month). ${ }^{(56)}$ In another study of 10 children refractory to systemic immunosuppression, monthly treatment for 2 years was associated with significant symptomatic improvement, fewer infection-related exacerbations, a decrease in IgE, and being able to stop immunosuppressants in five cases. ${ }^{(57)}$ Small open-label and randomised prospective studies in adults have had mixed outcomes but suggested benefit when used as adjunctive therapy. ${ }^{(58)}$

Treatment of atopic dermatitis with intramuscular immunoglobulin has been described in a pilot study of 17 adults. ${ }^{(59)} \mathrm{A}$ regimen of $50 \mathrm{mg}$ of autologous immunoglobulin twice weekly for 4 weeks was associated with a significant decrease in SCORAD and followed by remission for at least 8 weeks, with no evident side effects. 
Adverse effects of IVIG are usually minor and self-limiting, and result from aggregate formation of gamma globulin complexes with subsequent complement activation. Premedication with systemic corticosteroids, antihistamines and NSAIDs, and slowing the rate of infusion, can minimise adverse effects.

The expense and paucity of supply limits the use of immunoglobulin therapy.

\section{Interferon-gamma}

A double-blind placebo controlled trial of interferon- $\gamma$ randomised 83 adults and children with severe atopic dermatitis to $50 \mu \mathrm{g} / \mathrm{m}^{2}$ daily for 12 weeks, or placebo.(60) Those randomised to active treatment had a statistically significant improvement in symptoms. There was a reduction in eosinophil counts, which was considered a biomarker of treatment response. The response in children was better than in adults. Efficacy has been confirmed in subsequent studies including a placebocontrolled trial of thrice-weekly dosing in 51 patients. (61) Czarnowicki (62) reported that patients with severe atopic dermatitis had a deficiency of T cell-derived interferon in skin-homing T cells and defective responses to bacterial infection.

Side effects including influenza-like symptoms (headache, malaise, fever, myalgia), transient elevation of liver enzymes and neutropenia limits it's usability.

\section{Alitretinoin}

Alitretinoin (9-cis-retinoic acid), a first-generation retinoid, is licenced in some countries as an oral treatment for severe chronic hand dermatitis and is particularly effective in the hyperkeratotic subtype. A number of randomised placebo-controlled studies have established its efficacy, including a multicentre trial in 1,032 patients. (63) Patients were assigned to alitretinoin $10 \mathrm{mg}$ or $30 \mathrm{mg}$, or placebo, for 24 weeks with $48 \%$ achieving clearance. The median time to relapse, while not using any systemic therapy, was 6 months. Improvement has also been seen in patients' atopic dermatitis, $(64,65)$ but specific atopic dermatitis trials are needed.

\section{$\underline{\text { Vitamin D }}$}

This article is protected by copyright. All rights reserved 
Vitamin D stimulates the expression of antimicrobial peptides, decreases proinflammatory cytokine expression, increases regulatory cytokine expression leading to reduced $\mathrm{T}$ cell activation, and facilitates the production of profilaggrin and the lipid lamellae essential for skin barrier function.

A recent systematic review concluded that there is a significant inverse correlation between vitamin D levels and severity of atopic dermatitis. (66) Fourteen of 21 studies reported a significant reduction in disease severity with supplementation, although its efficacy remains controversial. A 2016 systematic review analysed the effects of vitamin $\mathrm{D}$ supplementation in patients with atopic dermatitis; they found four randomised controlled trials comparing vitamin D with a placebo; vitamin D supplementation showed a higher mean difference in severity symptoms (mean difference of -5.81).(67) Perversely, vitamin D supplementation in the first year of life may increase the risk of later atopic disease.(68)

Large prospective studies using differing doses and durations of vitamin D supplementation are needed.

\section{Vitamin E}

Vitamin E supplementation has been shown to decrease serum IgE in atopic patients. A randomised double-blind trial in 70 patients with mild to moderate atopic dermatitis compared 4 months' treatment with vitamin E (400 IU/day) or placebo. ${ }^{(69)}$ Improvement in symptoms were observed after 3 months. However, a 2012 Cochrane systematic review found no convincing evidence of the benefit of dietary supplements in atopic dermatitis. ${ }^{(70)}$

\section{New therapies}

With an increased understanding of the cytokine pathways of atopic dermatitis, new specific targeted therapies have been developed, including monoclonal antibodies and small molecules. ${ }^{(71,72) ~ ' S m a l l ~ m o l e c u l e ' ~ d r u g s ~ h a v e ~ a ~ l o w ~ m o l e c u l a r ~ w e i g h t, ~ a r e ~}$ able to enter cells, and can directly influence second messenger pathways. The data are still immature for many of these newer agents, but many show promise. Because 
of their significantly greater costs, they are likely to be used after failure of conventional systemic agents, unless data emerges that they are curative.

At this moment in time, the group felt it appropriate that patients should have tried and failed, or be contraindicated, to conventional systemic therapies (at least two of phototherapy, ciclosporin, methotrexate, azathioprine, or mycophenolate), over a period of at least six months, before considering one of the newer agents.

Monoclonal antibodies

$\underline{I L-4 / 13 \text { antagonists }}$

Dupilumab, a human monoclonal antibody against interleukin (IL)-4 receptor alpha, inhibits signalling of both IL-4 and IL-13, which are type 2 cytokines that drive atopic dermatitis.(73) Two identical phase 3 trials, SOLO 1 and SOLO 2, randomised a total of 1,379 adults with moderate to severe atopic dermatitis inadequately controlled by topical treatment to 16 weeks' treatment with dupilumab $300 \mathrm{mg}$ weekly, dupilumab $300 \mathrm{mg}$ every other week, or placebo.(73) The primary outcome was the proportion of patients who had both a score of 0 or 1 (clear or almost clear) on the Investigator's Global Assessment (IGA) and a reduction of 2 points or more in that score from baseline at week 16.

In SOLO 1 the primary outcome was achieved in $37 \%$ of those who received dupilumab weekly, $38 \%$ of patients who received dupilumab every other week, and $10 \%$ of those who received placebo $(\mathrm{P}<0.001)$. The results were similar in SOLO 2 $(36 \%, 36 \%$ and $8 \%$, respectively). Injection-site reactions and conjunctivitis were more frequent in the dupilumab groups.

A subsequent study randomised 740 patients to the regimens used in the SOLO studies but for 1 year. ${ }^{(74)}$ All three groups were also treated with topical corticosteroids or calcineurin inhibitors. The study showed that dupilumab, when added to standard topical corticosteroid treatment, improved atopic dermatitis signs and symptoms with acceptable safety, with 39\% achieving IGA 0/1 compared 
to $12 \%$ on placebo and topical corticosteroids. Dupilumab is now indicated for the treatment of atopic dermatitis.

\section{$\underline{\text { IL-13 antagonists }}$}

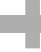

IL-13 is a pleiotropic type 2 cytokine implicated in the pathogenesis of atopic dermatitis; tralokinumab and lebrikizumab are anti IL-13 monoclonal antibodies. In a phase $2 \mathrm{~b}$ study, 204 adults with moderate to severe atopic dermatitis were randomised to receive 45,150 , or $300 \mathrm{mg}$ of subcutaneous tralokinumab or placebo every 2 weeks for 12 weeks with concomitant topical corticosteroids. ${ }^{(75)}$ At week 12, tralokinumab $300 \mathrm{mg}$ significantly improved EASI compared to placebo and a greater percentage of participants achieved an IGA response, defined as a 0/1 score or reduction of at least 2 grades from baseline (26.7\% vs 11.8\%). Participants also demonstrated improvements in SCORAD, DLQI, and pruritus scores versus placebo.

The phase 2 TREBLE study investigated the efficacy and safety of lebrikizumab as an add-on to topical corticosteroid treatment in 209 adults with moderate to severe atopic dermatitis. ${ }^{(76)}$ It compared lebrikizumab $125 \mathrm{mg}$ single dose, $250 \mathrm{mg}$ single dose or 125 mg every 4 weeks for 12 weeks, or placebo every 4 weeks for 12 weeks. At week 12, significantly more patients achieved EASI-50 with lebrikizumab $125 \mathrm{mg}$ every 4 weeks than placebo (82.4\% vs. 62.3\%, $\mathrm{P}=0.026)$. Adverse events were similar between groups.

\section{IL-31 antagonists}

There is increasing evidence that IL-31 has a key role in the pathogenesis of atopic dermatitis and pruritus. Nemolizumab, a humanised antibody against IL-31 receptor A, was investigated in a phase 2, 12-week trial in 264 patients with moderate-tosevere atopic dermatitis inadequately controlled by topical treatments. ${ }^{(77)}$ They were randomised to subcutaneous nemolizumab $0.1 \mathrm{mg}, 0.5 \mathrm{mg}$, or $2.0 \mathrm{mg} / \mathrm{kg}$ or placebo every 4 weeks. At week 12, among the patients who received nemolizumab every 4 weeks, the scores on the pruritus visual-analogue scale were reduced by $43.7 \%$ in the $0.1 \mathrm{mg}$ group, $59.8 \%$ in the $0.5 \mathrm{mg}$ group, and $63.1 \%$ in the $2.0 \mathrm{mg}$ group compared to $20.9 \%$ in the placebo group ( $\mathrm{P}<0.01$ for all comparisons). This article is protected by copyright. All rights reserved 
Reductions in the EASI were $23.0 \%, 42.3 \%, 40.9 \%$, respectively in the nemolizumab groups, and $26.6 \%$ in the placebo group.

\section{Other biologics}

mationa

Omalizumab is a monoclonal antibody that blocks IgE function, indicated for the treatment of chronic urticaria. To date, studies in atopic dermatitis are disappointing with an open-label study in 21 patients, four case series totalling 64 patients, and two small randomised controlled trials in a total of 28 patients not providing convincing evidence of efficacy. $(78,79)$

Mepolizumab, a monoclonal antibody to IL-5 that reduces peripheral blood eosinophils, failed to show a significant clinical benefit in a randomised controlled trial of 40 patients with atopic dermatitis. ${ }^{(80)}$ Although treatment led to a reduction in peripheral blood eosinophils, a subsequent analysis showed there was no effect on numbers of tissue eosinophils in skin biopsies.

The monoclonal anti-CD20 antibody rituximab depletes B cells, which are thought to have a central role in the pathogenesis of atopic dermatitis. A study in 6 patients administered two doses of rituximab $1000 \mathrm{mg}$, 2 weeks apart.(81) All patients showed an improvement of their skin symptoms within 4 to 8 weeks with EASI falling from 29.4 at baseline to 8.4 at week $8(\mathrm{P}<0.001)$.

An open label study treated 9 patients with the TNF- $\alpha$ antagonist infliximab at weeks $0,2,6,14,22,30$, and 38.(82) There was a significant improvement in various clinical parameters during the induction phase, but this was not sustained during maintenance.

Ustekinumab, indicated for the treatment of psoriasis, targets the shared p40 subunit of IL-12 and IL-23. A phase 2 study randomised 33 patients to either ustekinumab or placebo at weeks 0,4 , and 16 with a crossover to the other agent at weeks 16, 20, and 32.(83) The ustekinumab group achieved higher SCORAD50 responses at weeks 12, 16 (the primary endpoint) and 20 compared to placebo, but the difference between groups was not significant. 
Thymic stromal lymphopoietin (TSLP) is a cytokine produced by epithelial cells, induced by pro-inflammatory stimuli, which drives Th2 responses; tezepelumab binds to, and blocks, thymic stromal lymphopoietin (TSLP). In a phase 2a study in 113 patients, a numerically greater percentage of tezepelumab-treated patients achieved EASI50 compared to placebo (64.7\% vs. $48.2 \%, \mathrm{P}=0.091) .{ }^{(84)}$ Greater than expected response rates in placebo-treated patients were possibly attributable to the concomitant use of topical corticosteroids permitted in the study.

The group considered that, at this moment in time, the data for the efficacy of various monoclonal antibodies remains immature, other than that of dupliumab. Because of expense, it is likely that dupilumab use will be after other established systemic agents (e.g. phototherapy, systemic corticosteroids, ciclosporin, methotrexate, mycophenolate or azathioprine).

Small molecules

\section{Apremilast}

Phosphodiesterase-4 is a key regulator of inflammatory cytokine production in atopic dermatitis through its effects on the degradation of cAMP. The oral phosphodiesterase-4 inhibitor apremilast, indicated for psoriasis/psoriatic arthritis, is anti-inflammatory with minimal immunosuppressive effects. In a phase 2 study in 10 patients with 'recalcitrant' atopic dermatitis, only 2 patients achieved the primary endpoint of $a \geq 2$ point improvement in IGA at week 12.(85) In a phase 2 study in 191 adults with moderate to severe atopic dermatitis, apremilast did not achieve the primary endpoint of improvement in EASI compared to placebo (NCT02087943). It has a narrow therapeutic window for gastrointestinal adverse events including nausea, diarrhoea and dyspepsia; depression/suicide has been reported.

\section{JAK inhibitors}

The Janus kinase (JAK) associated pathways are utilised by a number of cytokines as they bind to their specific receptors and activate downstream signal transduction. 
Cytokines dependent on JAK include IL-2 (which enhances effector and regulatory responses), IL-9 (atopic disease and inflammatory bowel disease), IL-5 (allergies, asthma and eosinophilic disease) and IL-6 (the prototypic proinflammatory cytokine implicated in many autoimmune disorders). ${ }^{(86,87)}$

Baricitinib, a first-generation JAK inhibitor is selective for JAK1 and JAK2 over JAK3. A phase 2 study randomised 124 patients with moderate to severe atopic dermatitis to placebo, $2 \mathrm{mg}$ or $4 \mathrm{mg} /$ day baricitinib for 16 weeks. ${ }^{(88)}$ Use of topical corticosteroids was permitted during the study. Significantly more baricitinib $4 \mathrm{mg}$ patients achieved EASI50 compared to placebo at 16 weeks (61\% vs. $37 \%, \mathrm{P}=0.027$ ), with benefit evident as early as week 4 . Baricitinib also improved pruritus and sleep loss. Phase 3 trials are in progress.

Upadacitinib, a second-generation selective JAK1 inhibitor, has been investigated in rheumatoid arthritis, Crohn disease, ulcerative colitis and atopic dermatitis. Sixteenweek results are available from a phase $2 \mathrm{~b}$ study in 165 adults with moderate to severe atopic dermatitis not adequately controlled by topical treatments, or for whom topical treatments were not medically advisable. ${ }^{(89)}$ The EASI score at week 16 was reduced by $74 \%$ in patients randomised to upadacitinib $30 \mathrm{mg} /$ day, ( $\mathrm{P}<0.001$ vs. placebo), $62 \%$ with upadacitinib $15 \mathrm{mg}(\mathrm{P}<0.001), 39 \%$ with upadacitinib $7.5 \mathrm{mg}(\mathrm{P}<0.05)$ and $23 \%$ with placebo. The most common adverse events were upper respiratory tract infection, paradoxical worsening of atopic dermatitis, and worsening of acne. Phase 3 trials are in progress.

A pilot study of tofacitinib in 6 patients with moderate to severe disease who had failed standard treatment reported a reduction in affected body surface area, erythema, oedema/papulation, lichenification and excoriation. ${ }^{(90)}$ The SCORAD decreased from 36.5 to $12.2(\mathrm{P}<0.05)$ during 8 to 29 weeks of treatment. There were no adverse events. Despite these promising results no further studies of tofacitinib appear to have been planned.

\section{When to stop}

This article is protected by copyright. All rights reserved 
There are four main reasons for stopping a systemic agent: lack of response, adverse effects, achieving remission or the patients withdraw their consent. There is no clear definition of a lack of response as it is a complex interplay between pharmacological responses, the natural history of the disease and the patients' expectations. (91) Whilst reduction in clinical scores is important, improvement in patient related outcome measures (e.g. DLQI) should be the main consideration. The minimal clinically important difference (MCID) in DLQI is a reduction by 4 points, but the goal is to achieve a score of 0 or 1 . However, there can be a significant delay between achieving a complete clinical response and achieving a DLQI of 0/1, particularly as itch may persist for many months after 'clearing' the skin. The timing of making a 'lack of response' decision needs to take into account the pharmacodynamics of the various agents (e.g. systemic corticosteroids 2-4 weeks, ciclosporin 4-8 weeks, dupilumab 12 weeks, methotrexate or azathioprine 12-16 weeks).

Stopping because of significant adverse effects is often determined by the clinician's risk assessment and/or patient's tolerability, and will vary with co-morbidities, age, and the specific drug being used. Dose adjustment, short term withholding of the systemic agent and co-prescribing (e.g. omeprazole, antihypertensive, anti-emetic, etc.) may be sufficient.

Whilst determining remission is relatively straightforward, the timing of stopping the systemic agent is more difficult. There is little evidence base to direct how long treatment should be continued. None of the current systemic agents are curative, so relapse is not uncommon. There was heterogeneity in the group with some recommending tapering/stopping as soon as clinical improvement occurred, but with no hard definition of what constituted clinical improvement, and others in the group recommending to continue treatment ( \pm taper) for a number of months after complete clinical response, acknowledging that this could be many years.

Members of the group recommended the first line systemic agent be re-evaluated after 3 months, to check adherence/compliance, patient satisfaction, and adverse 
effects; if at this stage the response was considered inadequate, to increase the dose, switch to a second agent or add in a second systemic agent (with dose adjustment of the first drug)(see Table 1). A lack of response should encourage a review of the clinical diagnosis and exclusion of significant trigger factors (e.g. infection, contact dermatitis, etc.). Depending on the patient's co-morbidities, the group were generally comfortable in switching between the four main systemic agents (ciclosporin, methotrexate, azathioprine and mycophenolate). Most were also comfortable in adding any two together (other than azathioprine with mycophenolate as they have a similar mode of action), but usually with a dose adjustment.

Several members noted that, if the patient had failed to show good initial clinical response to systemic steroids (prednisone/prednisolone 40-50 mg/day), then it was less likely that they would response to steroid sparing agents (methotrexate, azathioprine or mycophenolate).

The group also recommended consideration be given to short term hospital or day unit admission for wet wraps, either as a bridging treatment to systemic therapy, or as rescue treatment at any time.

\section{Summary}

Immune-modulatory agents are appropriate for patients with atopic dermatitis refractory to topical regimens and phototherapy, or when quality of life is significantly affected. There is a paucity of data indicating the relative efficacy of each systemic agent but ciclosporin, methotrexate, azathioprine and mycophenolate are all widely used. Whilst there is some evidence for other systemic agents, including interferon-gamma, montelukast, tacrolimus, and leflunomide, it is generally of poor quality and demonstrates only moderate improvement at best. The evidence of benefit for IVIG and systemic retinoids (alitretinoin) is also limited, but the potential improvements appear greater. Whilst guidelines recommend that systemic corticosteroids and systemic antibiotics should be avoided, they retain an important role in the management of a small number of patients.

This article is protected by copyright. All rights reserved 
There is little published data to recommend the sequencing of systemic therapies, their use in combinations, optimal dosing, and when to stop treatment for remission.

The data on the newer specific targeted therapies, including monoclonal antibiotics and small molecules, is very encouraging, but cost may limit their availability. For this reason, it is reasonable for patients to have tried and failed, or be contraindicated to at least two conventional systemic therapies (phototherapy, ciclosporin, methotrexate, azathioprine, or mycophenolate), over a period of at least six months.

\section{References}

1. LePoidevin LM, Lee DE, Shi VY. A comparison of international management guidelines for atopic dermatitis. Pediatr Dermatol. 2019;36:36-65.

2. Sidbury R, Kodama S. Atopic dermatitis guidelines: Diagnosis, systemic therapy, and adjunctive care. Clin Dermatol. 2018;36:648-52.

3. Wollenberg A, Barbarot S, Bieber T, Christen-Zaech S, Deleuran M, Fink-Wagner A, Gieler U, Girolomoni G, Lau S, Muraro A, Czarnecka-Operacz M, Schäfer T, SchmidGrendelmeier P, Simon D, Szalai Z, Szepietowski JC, Taïeb A, Torrelo A, Werfel T, Ring J; European Dermatology Forum (EDF), the European Academy of Dermatology and Venereology (EADV), the European Academy of Allergy and Clinical Immunology (EAACI), the European Task Force on Atopic Dermatitis (ETFAD), European Federation of Allergy and Airways Diseases Patients' Associations (EFA), the European Society for Dermatology and Psychiatry (ESDaP), the European Society of Pediatric Dermatology (ESPD), Global Allergy and Asthma European Network (GA2LEN) and the European Union of Medical Specialists (UEMS). Consensus-based European guidelines for treatment of atopic eczema (atopic dermatitis) in adults and children: part I. J Eur Acad Dermatol Venereol. 2018;32:657-82. 
4. Wollenberg A, Barbarot S, Bieber T, Christen-Zaech S, Deleuran M, Fink-Wagner A, Gieler U, Girolomoni G, Lau S, Muraro A, Czarnecka-Operacz M, Schäfer T, SchmidGrendelmeier P, Simon D, Szalai Z, Szepietowski JC, Taïeb A, Torrelo A, Werfel T, Ring J; European Dermatology Forum (EDF), the European Academy of Dermatology and Venereology (EADV), the European Academy of Allergy and Clinical Immunology (EAACI), the European Task Force on Atopic Dermatitis (ETFAD), European Federation of Allergy and Airways Diseases Patients' Associations (EFA), the European Society for Dermatology and Psychiatry (ESDaP), the European Society of Pediatric Dermatology (ESPD), Global Allergy and Asthma European Network (GA2LEN) and the European Union of Medical Specialists (UEMS). Consensus-based European guidelines for treatment of atopic eczema (atopic dermatitis) in adults and children: part II. J Eur Acad Dermatol Venereol. 2018;32:850-78.

5. de María Díaz Granados L, Quijano MA, Ramírez PA, Aguirre N, Sanclemente G. Quality assessment of atopic dermatitis clinical practice guidelines in $\leq 18$ years. Arch Dermatol Res. 2018;310:29-37.

6. Simpson EL, Bruin-Weller M, Flohr C, Ardern-Jones MR, Barbarot S, Deleuran M, Bieber T, Vestergaard C, Brown SJ, Cork MJ, Drucker AM, Eichenfield LF, FoelsterHolst R, Guttman-Yassky E, Nosbaum A, Reynolds NJ, Silverberg JI, Schmitt J, Seyger MMB, Spuls PI, Stalder JF, Su JC, Takaoka R, Traidl-Hoffmann C, Thyssen JP, van der Schaft J, Wollenberg A, Irvine AD, Paller AS. When does atopic dermatitis warrant systemic therapy? Recommendations from an expert panel of the International Eczema Council. J Am Acad Dermatol. 2017;77:623-33.

7. Armstrong A, Huang A, Wang L, Miao R, Patel, M; Wei W. Real-world utilization patterns of systemic immunosuppressants among US adult patients with atopic dermatitis. JAm Acad Dermatol. 2017;76 (Suppl 1):AB215.

8. Armstrong A, Moon R, Bell D, Blackburn S, Wei W, Chao J. Real-world disease burden in US adults with moderate-to-severe atopic dermatitis eligible for 
treatment with systemic immunosuppressants. J Am Acad Dermatol. 2017;76(Suppl 1):AB215.

9. Lynde CW, Bourcier M, Gooderham M, Guenther L, Hong CH, Papp KA, Poulin Y, Sussman G, Vender R. A Treatment Algorithm for Moderate to Severe Atopic Dermatitis in Adults. J Cutan Med Surg. 2018;22:78-83.

10. Totri CR, Eichenfield LF, Logan K, Proudfoot L, Schmitt J, Lara-Corrales I, Sugarman J, Tom W, Siegfried E, Cordoro K, Paller AS, Flohr C. Prescribing practices for systemic agents in the treatment of severe pediatric atopic dermatitis in the US and Canada: The PeDRA TREAT survey. J Am Acad Dermatol. 2017;76:281-5.

11. Drucker AM, Eyerich K, de Bruin-Weller MS, Thyssen JP, Spuls PI, Irvine AD, Girolomoni G, Dhar S, Flohr C, Murrell DF, Paller AS, Guttman-Yassky E. Use of systemic corticosteroids for atopic dermatitis: International Eczema Council consensus statement. Br J Dermatol. 2018;178:768-75.

12. Barnes PJ, Adcock IM. Glucocorticoid resistance in inflammatory diseases. Lancet. 2009;373:1905-17.

13. Sonenthal KR, Grammer LC, Patterson R. Do some patients with atopic dermatitis require long-term oral steroid therapy? J Allergy Clin Immunol. 1993;91:971-3

14. Heddle RJ, Soothill JF, Bulpitt CJ, Atherton DJ. Combined oral and nasal beclomethasone diproprionate in children with atopic eczema: a randomized controlled trial. Br Med J (Clin Res Ed). 1984;289:651-4

15. Aylett SE, Atherton DJ, Preece MA. The treatment of difficult atopic dermatitis in childhood with oral beclomethasone diproprionate. Acta Derm Venereol (Stockh). 1992;1992:123-5.

16. La Rosa M, Musarra I, Ranno C et al. A randomized, double-blind, placebocontrolled, crossover trial of systemic flunisolide in the treatment of children with severe atopic dermatitis. Curr Ther Res. 1995;56:720-6.

This article is protected by copyright. All rights reserved 
17. Schmitt J, Schakel K, Folster-Holst R, et al. Prednisolone vs. ciclosporin for severe adult eczema. An investigator-initiated double-blind placebo-controlled multicentre trial. Br J Dermatol. 2010;162:661-8.

18. Steinke S, Langenbruch A, St€ander S, Franzke N, Augustin M. Therapeutic benefits in atopic dermatitis from patients' perspective: results of the German national health care study 'Atopic Health'. Dermatology. 2014;228:350-9.

19. Stroud GM, Miller RE, Kozikoski ES. Oral versus intramuscular methylprednisolone. A double-blind study. Arch Dermatol. 1963;1963:710-4.

20. Reddy S, Ananthakrishnan S, Garg A. A prospective observational study evaluating hypothalamic-pituitary-adrenal axis alteration and efficacy of intramuscular triamcinolone acetonide for steroid-responsive dermatologic disease. J Am Acad Dermatol. 2013;69:226-31.

21. Galli E, Chini L, Moschese V, Paone F, Menichelli A, Fraioli G, Rossi P. Methylprednisolone bolus: a novel therapy for severe atopic dermatitis. Acta Paediatr. 1994;83:315-7.

22. Khan SA, Smith AF. Tetracosactrin-depot therapy in dermatology. B J Dermatol. 1970;82:389-96.

23. Munro DD. Corticotrophin and tetracosactrin depot-self administered for the treatment of eczema. Br J Dermatol. 1976;94(Suppl12):135-8.

24. Broersen LH, Pereira AM, Jørgensen JO, Dekkers OM. Adrenal insufficiency in corticosteroid use: systematic review and meta-analysis. J Clin Endocrinol Metab. 2015;100:2171-80.

25. Carmichael SL, Shaw GM. Maternal corticosteroid use and risk of selected congenital anomalies. Am J Med Genet. 1999;86:242-4.

26. Rayburn WF. Glucocorticoid therapy for rheumatic diseases: maternal, fetal, and breast-feeding considerations. Am J Reprod Immunol. 1992;28:138-40. 
27. Rademaker M, Gupta M, Andrews M, Armour K, Baker C, Foley P, Gebauer K, George J, Rubel D, Sullivan J. The Australasian Psoriasis Collaboration view on Methotrexate for psoriasis in the Australasian setting. Australas J Dermatol. 2017;58:166-170.

28. Roekevisch E, Spuls PI, Kuester D, Limpens J, Schmitt J. Efficacy and safety of systemic treatments for moderate-to-severe atopic dermatitis: a systematic review. J Allergy Clin Immunol. 2014;133:429-38.

29. Weatherhead SC, Wahie S, Reynolds NJ, Meggitt SJ. An open-label, dose-ranging study of methotrexate for moderate-to-severe adult atopic eczema. Br J Dermatol. 2007;156:346-51.

30. Schram ME, Roekevisch E, Leeflang MM, Bos JD, Schmitt J, Spuls PI. A randomized trial of methotrexate versus azathioprine for severe atopic eczema. J Allergy Clin Immunol. 2011;128:353-9.

31. Roekevisch E, Schram ME, Leeflang MM, Brouwer MW, Gerbens LA, Bos JD, Spuls PI. Methotrexate versus azathioprine in patients with atopic dermatitis: 2-year follow-up data. J Allergy Clin Immunol. 2018;141 825-7.e10.

32. Goujon C, Viguier M, Staumont-Sallé D, Bernier C, Guillet G, Lahfa M, Ferrier Le Bouedec MC, Cambazard F, Bottigioli D, Grande S, Dahel K, Bérard F, Rabilloud M, Mercier C, Nicolas JF. Methotrexate versus cyclosporine in adults with moderate-to-severe atopic dermatitis: a phase III randomized non inferiority trial. J Allergy Clin Immunol Pract. 2018;6:562-9.

33. Law Ping Man S, Bouzillé G, Beneton N, Safa G, Dupuy A, Droitcourt C. Drug survival and postdrug survival of first-line immunosuppressive treatments for atopic dermatitis: comparison between methotrexate and cyclosporine. J Eur Acad Dermatol Venereol. 2018 Feb 14. doi: 10.1111/jdv.14880.

34. Politiek K, van der Schaft J, Coenraads PJ, de Bruin-Weller MS, Schuttelaar MLA. Drug survival for methotrexate in a daily practice cohort of adult patients with severe atopic dermatitis. Br J Dermatol. 2016;174:201-3.

This article is protected by copyright. All rights reserved 
35. Delcasso B, Goujon C, Hacard F, Delcroix F, Grande S, Berard F, Nicolas JF, Nosbaum A. Tolerance of methotrexate in a daily practice cohort of adults with atopic dermatitis. Eur J Dermatol. 2018;28:266-7.

36. Harper JI, Ahmed I, Barclay G, Lacour M, Hoeger P, Cork MJ, Finlay AY, Wilson NJ, Graham-Brown RA, Sowden JM, Beard AL, Sumner MJ, Berth-Jones J. Cyclosporin for severe childhood atopic dermatitis: short course versus continuous therapy. Br J Dermatol. 2000;142:52-8.

37. Granlund H, Erkko P, Sinisalo M, Reitamo S. Cyclosporin in atopic dermatitis: time to relapse and effect of intermittent therapy. Br J Dermatol. 1995;132:106-12.

38. Sidbury R, Davis DM, Cohen DE, Cordoro KM, Berger TG, Bergman JN, et al. Guidelines of care for the management of atopic dermatitis: section 3. Management and treatment with phototherapy and systemic agents. J Am Acad Dermatol. 2014;71:327-49.

39. Gerosa M, Meroni PL, Cimaz R. Safety considerations when prescribing immunosuppression medication to pregnant women. Expert Opin Drug Saf. 2014;13:1591-9.

40. Muellenhoff MW, Koo JY. Cyclosporine and skin cancer: an international dermatologic perspective over 25 years of experience. A comprehensive review and pursuit to define safe use of cyclosporine in dermatology. J Dermatolog Treat. 2012;23:290-304.

41. Meggitt SJ, Gray JC, Reynolds NJ. Azathioprine dosed by thiopurine methyltransferase activity for moderate-to-severe atopic eczema: a double-blind, randomized controlled trial. Lancet. 2006;367:839-46.

42. Berth-Jones J, Takwale A, Tan E, Barclay G, Agarwal S, Ahmed I, Hotchkiss K, Graham-Brown RA. Azathioprine in severe adult atopic dermatitis: a double-blind, placebo-controlled, crossover trial. Br J Dermatol. 2002;147:324-30. 
43. Haeck IM, Knol MJ, Ten Berge O, van Velsen SG, de Bruin-Weller MS, BruijnzeelKoomen CA. Enteric-coated mycophenolate sodium versus cyclosporin A as longterm treatment in adult patients with severe atopic dermatitis: a randomized controlled trial. J Am Acad Dermatol. 2011;64:1074-84.

44. Dréno B, Araviiskaia E, Berardesca E, Gontijo G, Sanchez Viera M, Xiang LF, Martin R, Bieber T. Microbiome in healthy skin, update for dermatologists. J Eur Acad Dermatol Venereol. 2016;30:2038-47.

45. Thomas CL, Fernández-Peñas P. The microbiome and atopic eczema: More than skin deep. Australas J Dermatol. 2017;58:18-24.

46. Hepburn L, Hijnen DJ, Sellman BR, Mustelin T, Sleeman MA, May RD, Strickland I. The complex biology and contribution of Staphylococcus aureus in atopic dermatitis, current and future therapies. Br J Dermatol. 2017;177:63-71.

47. Ong PY. Recurrent MRSA skin infections in atopic dermatitis. J Allergy Clin Immunol Pract. 2014;2:396-9.

48. Hsu CJ, Wang LF. Emerging treatment of atopic dermatitis. Clin Rev Allergy Immunol. 2007;33:199-203.

49. Schmitt J, Wozel G, Pfeiffer C. Leflunomide as a novel treatment option in severe atopic dermatitis. Br J Dermatol. 2004;150:1182-5.

50.. Chin WK, Lee SWH. A systematic review on the off-label use of montelukast in atopic dermatitis treatment. Int J Clin Pharm. 2018;40:963-76.

51. Cavero-Carbonell C, Vinkel-Hansen A, Rabanque-Hernández MJ, Martos C, Garne E. Fetal Exposure to Montelukast and Congenital Anomalies: A Population Based Study in Denmark. Birth Defects Res. 2017;109:452-9.

52. Keaney TC, Bhutani T, Sivanesan P, Bandow GD, Weinstein SB, Cheung LC, Malic k F, Koo J. Open-label, pilot study examining sequential therapy with oral tacrolimus and topical tacrolimus for severe atopic dermatitis. J Am Acad Dermatol. 2012;67:636-41.

This article is protected by copyright. All rights reserved 
53. van der Schaft J, van Schaik RH, van Zuilen AD, Hijnen DJ, Berg MT, van den Broek MP, Bruijnzeel-Koomen CA, de Bruin-Weller MS. First experience with extended release tacrolimus in the treatment of adult patients with severe, difficult to treat atopic dermatitis: Clinical efficacy, safety and dose finding. J Dermatol Sci. 2016;81:66-8.

54. Lee FJ, Frankum BS, Katelaris CH. Poor efficacy of oral tacrolimus in the treatment of severe generalized atopic eczema in adults: a small retrospective case series. Australas J Dermatol. 2012;53:295-7.

55. Schroer B, Lockey R. Oral tacrolimus for severe recalcitrant atopic eczema. J. Allergy Clin Immunol. 2003;111:1409-10.

56. Jee SJ, Kim JH, Baek HS, Lee HB, Oh JW. Long-term efficacy of intravenous immunoglobulin therapy for moderate to severe childhood atopic dermatitis. Allergy Asthma Immunol Res. 2011;3:89-95.

57. Turner PJ, Kakakios A, Wong LC, Wong M, Campbell DE. Intravenous immunoglobulin to treat severe atopic dermatitis in children: a case series. Pediatr Dermatol. 2012;29:177-81.

58. Jolles S, Sewell C, Webster D, Ryan A, Heelan B, Waite A, Rustin M. Adjunctive high-dose intravenous immunoglobulin treatment for resistant atopic dermatitis: efficacy and effects on intracellular cytokine levels and CD4 counts. Acta Derm Venereol. 2003;83:433-7.

59. Nahm DH, Kim ME, Cho SM. Effects of intramuscular injection of autologous immunoglobulin on clinical severity and serum IgE concentration in patients with atopic dermatitis. Dermatology. 2015:231:145-51.

60. Hanifin JM, Schneider LC, Leung DY, Ellis CN, Jaffe HS, Izu AE, Bucalo LR, Hirabayashi SE, Tofte SJ, Cantu-Gonzales G, et al. Recombinant interferon gamma therapy for atopic dermatitis. J Am Acad Dermatol. 1993;28:189-97. 
61. Jang IG, Yang JK, Lee HJ, Yi JY, Kim HO, Kim CW, Kim TY. Clinical improvement and immunohistochemical findings in severe atopic dermatitis treated with interferon gamma. J Am Acad Dermatol. 2000;42:1033-40.

62. Czarnowicki T, Gonzalez J, Shemer A, Malajian D, Xu H, Zheng X, Khattri S, Gilleaudeau P, Sullivan-Whalen M, Suárez-Fariñas M, Krueger JG, Guttman-Yassky E. Severe atopic dermatitis is characterized by selective expansion of circulating Th2/Tc2 and Th22/Tc22 but not Th17/Tc17 cells within the skin homing T cell population. J Allergy Clin Immunol. 2015;136:104-15.

63. Ruzicka T, Lynde CW, Jemec GB, Diepgen T, Berth-Jones J, Coenraads PJ, Kaszuba A, Bissonnette R, Varjonen E, Holló P, Cambazard F, Lahfa M, Elsner P, Nyberg F, Svensson A, Brown TC, Harsch M, Maares J. Efficacy and safety of oral alitretinoin (9cis retinoic acid) in patients with severe chronic hand eczema refractory to topical corticosteroids: results of a randomized, double-blind, placebo-controlled, multicentre trial. Br J Dermatol. 2008;158:808-17.

64. Grahovac M, Molin S, Prinz JC, Ruzicka T, Wollenberg A. Treatment of atopic eczema with oral alitretinoin. Br J Dermatol. 2010;162:217-8.

65. Schmitt J, Abraham S, Trautmann F, Stephan V, Fölster-Holst R, Homey B, Bieber T, Novak N, Sticherling M, Augustin M, Kleinheinz A, Elsner P, Weidinger S, Werfel T. Usage and effectiveness of systemic treatments in adults with severe atopic eczema: First results of the German Atopic Eczema Registry TREATgermany. J Dtsch Dermatol Ges. 2017;15:49-59.

66. Huang CM, Lara-Corrales I, Pope E. Effects of Vitamin D levels and supplementation on atopic dermatitis: A systematic review. Paediatr Dermatol. 2018;35:754-60.

67. Kim G, Bae JH. Vitamin D and atopic dermatitis: A systematic review and metaanalysis. Nutrition. 2016;32:913-20.

This article is protected by copyright. All rights reserved 
68. E, Sovio U, Wjst M, Patel S, Pekkanen J, Hartikainen AL, Järvelinb MR. Infant Vitamin D supplementation and allergic conditions in adulthood: northern Finland birth cohort 1996. Ann N Y Acad Sci. 2004:1037:84-95.

69. Jaffary F, Faghihi G, Mokhtarian A, Hosseini SM. Effects of oral vitamin E on treatment of atopic dermatitis: A randomised trial. J Res Med Sci. 2015;20:1053-7. nat

70. Bath-Hextall FJ, Jenkinson C, Humphreys R, Williams HC. Dietary supplements for established atopic eczema. Cochrane Database Syst Rev. 2012;(2):CD005205.

71. Werfel T. Novel systemic drugs in treatment of atopic dermatitis: results from phase II and phase III studies published in 2017/2018. Curr Opin Allergy Clin Immunol. 2018;18:432-7.

72. Vakharia, P, Silverberg, J. New therapies for atopic dermatitis: Additional treatment classes. J Am Acad Dermatol. 2018;78:S76-83.

73. Simpson EL, Bieber T, Guttman-Yassky E, Beck LA, Blauvelt A, Cork MJ, Silverberg JI, Deleuran M, Kataoka Y, Lacour JP, Kingo K, Worm M, Poulin Y, Wollenberg A, Soo Y, Graham NM, Pirozzi G, Akinlade B, Staudinger H, Mastey V, Eckert L, Gadkari A, Stahl N, Yancopoulos GD, Ardeleanu M; SOLO 1 and SOLO 2 Investigators. Two phase 3 trials of dupilumab versus placebo in atopic dermatitis. N Engl/Med. 2016;375:2335-48.

74. Blauvelt A, de Bruin-Weller M, Gooderham M, Cather JC, Weisman J, Pariser D, Simpson EL, Papp KA, Hong HC, Rubel D, Foley P, Prens E, Griffiths CEM, Etoh T, Pinto PH, Pujol RM, Szepietowski JC, Ettler K, Kemény L, Zhu X, Akinlade B, Hultsch T, Mastey V, Gadkari A, Eckert L, Amin N, Graham NMH, Pirozzi G, Stahl N, Yancopoulos GD, Shumel B. Long-term management of moderate-to-severe atopic dermatitis with dupilumab and concomitant topical corticosteroids (LIBERTY AD CHRONOS): a 1year, randomised, double-blinded, placebo-controlled, phase 3 trial. Lancet. 2017;389:2287-303. 
75. Wollenberg A, Howell MD, Guttman-Yassky E, Silverberg JI, Kell C5, Ranade K, Moate R, van der Merwe R. Treatment of atopic dermatitis with tralokinumab, an anti-IL-13 mAb. J Allergy Clin Immunol. 2019;143:135-141.

76. Simpson EL, Flohr C, Eichenfield LF, et al. Efficacy and safety of lebrikizumab (an anti-IL-13 monoclonal antibody) in adults with moderate-to-severe atopic dermatitis inadequately controlled by topical corticosteroids: A randomized, placebo-controlled phase II trial (TREBLE). J Am Acad Dermatol. 2018;78:863-71.

77. Ruzicka T, Hanifin JM, Furue M, Pulka G, Mlynarczyk I, Wollenberg A, Galus R, Etoh T, Mihara R, Yoshida H, Stewart J, Kabashima K; XCIMA Study Group. Antiinterleukin-31 receptor A antibody for atopic dermatitis. N Engl J Med. 2017;376:826-35.

78. Holm JG, Agner T, Sand C, Thomsen SF. Omalizumab for atopic dermatitis: case series and a systematic review of the literature. Int J Dermatol. 2017;56:18-26.

79. Deleanu D, Nedelea I. Biological therapies for atopic dermatitis: An update. Exp Ther Med.2019;17:1061-7.

80. Oldhoff JM, Darsow U, Werfel T, Katzer K, Wulf A, Laifaoui J, Hijnen DJ, Plötz S, Knol EF, Kapp A, Bruijnzeel-Koomen CA, Ring J, de Bruin-Weller MS. Anti-IL-5 recombinant humanized monoclonal antibody (mepolizumab) for the treatment of atopic dermatitis. Allergy. 2005;60:693-6.

81. Simon D, Hösli S, Kostylina G, Yawalkar N, Simon HU. Anti-CD20 (rituximab) treatment improves atopic eczema. J Allergy Clin Immunol. 2008;121:122-8. ras

82. Jacobi A, Antoni C, Manger B, Schuler G, Hertl M. Infliximab in the treatment of moderate to severe atopic dermatitis. J Am Acad Dermatol. 2005;52:522-6.

83. Khattri S, Brunner PM, Garcet S, Finney R, Cohen SR, Oliva M, Dutt R, FuentesDuculan J, Zheng X, Li X, Bonifacio KM, Kunjravia N, Coats I, Cueto I, Gilleaudeau P, Sullivan-Whalen M, Suárez-Fariñas M, Krueger JG, Guttman-Yassky E. Efficacy and 
safety of ustekinumab treatment in adults with moderate-to-severe atopic dermatitis. Exp Dermatol. 2017;26:28-35.

84. Simpson EL, Parnes JR, She D, et al. Tezepelumab, an anti-TSLP monoclonal antibody, in the treatment of moderate to severe atopic dermatitis: A randomized phase 2a clinical trial. J Am Acad Dermatol. 2018 Dec 11. pii: S01909622(18)33050-0

85. Cotter DG, Schairer D, Eichenfield L. Volf EM, Au SC, Dumont N, Scheinman P, Gottlieb AB. A phase 2, open-label, investigator-initiated study to evaluate the safety and efficacy of apremilast in subjects with recalcitrant allergic contact or atopic dermatitis. J Drugs Dermatol. 2012;11:341-6.

86. Schwartz DM, Bonelli M, Gadina M, O'Shea JJ. Type I/II cytokines, JAKs, and new strategies for treating autoimmune diseases. Nat Rev Rheumatol. 2016;12:25-36. 87. Cotter DG, Schairer D, Eichenfield L. Emerging therapies for atopic dermatitis: JAK inhibitors. J Am Acad Dermatol. 2018;78(3 Suppl 1):S53-S62.

88. Guttman-Yassky E, Silverberg JI, Nemoto O, Forman SB, Wilke A, Prescilla R, de la Peña A, Nunes FP, Janes J, Gamalo M, Donley D, Paik J, DeLozier AM, Nickoloff BJ, Simpson EL. Baricitinib in adult patients with moderate-to-severe atopic dermatitis: a phase 2 parallel, double-blinded, randomized placebo-controlled multiple-dose study. J Am Acad Dermatol. 2018 Feb 1. pii: S0190-9622(18)30129-4.

89. Guttman-Yassky E, Anderson J, APangan A, et al. Primary results from a phase $2 \mathrm{~b}$, randomized, placebo-controlled trial of upadacitinib for patients with atopic dermatitis . American Academy of Dermatology Annual Meeting; Feb 16-20; San Diego 2018.

90. Levy LL, Urban J, King BA. Treatment of recalcitrant atopic dermatitis with the oral Janus kinase inhibitor tofacitinib citrate. J Am Acad Dermatol. 2015;73:395-9. 
91. Schram ME, Spuls PI, Leeflang MM, Lindeboom R, Bos JD, Schmitt J. EASI, (objective) SCORAD and POEM for atopic eczema: responsiveness and minimal clinically important difference. Allergy. 2012;67:99-106.

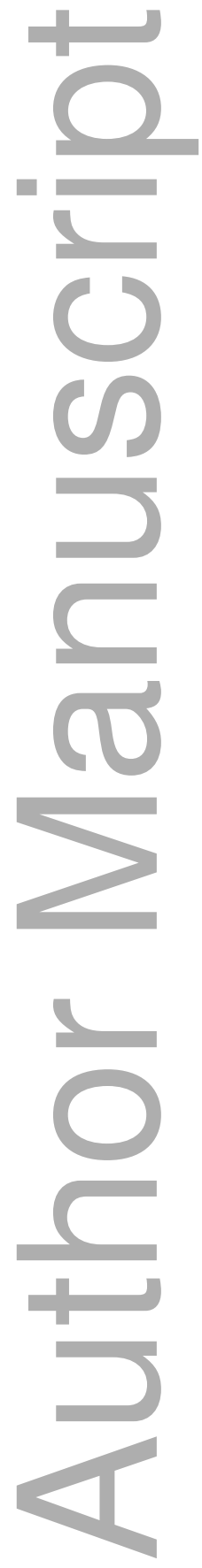

This article is protected by copyright. All rights reserved 
Table 1. Systemic therapy for adult atopic dermatitis (dosages are indicative only and are affected by renal function, lean body mass, co-morbidities and other drugs)

\begin{tabular}{|c|c|c|c|c|c|}
\hline Agent & \begin{tabular}{|l|l} 
st & line
\end{tabular} & $2^{\text {nd }}$ line & $3^{\text {rd }}$ line & As an add on & Monitoring \\
\hline $\begin{array}{l}\text { Prednisone/ } \\
\text { Prednisolone }\end{array}$ & $\begin{array}{l}\text { Bridging to methotrexate, } \\
\text { azathioprine or } \\
\text { mycophenolate: } \\
6-10 \text { weeks } \\
40-50 \mathrm{mg} / \text { day for } 1 \\
\text { week, } 20-25 \mathrm{mg} / \text { day for } \\
2 \text { weeks, } 10-12.5 \\
\text { mg/day for } 3 \text { weeks, }( \pm 5 \\
\text { mg/day for } 4 \text { weeks }) \\
\text { Rescue therapy: } \\
3-6 \text { days } \\
40-50 \mathrm{mg} \text { for } 2 \text { days, } 20- \\
25 \mathrm{mg} / \mathrm{day} \text { for } 2 \text { days, } \\
10-12.5 \mathrm{mg} / \text { day for } 2 \\
\text { days }\end{array}$ & 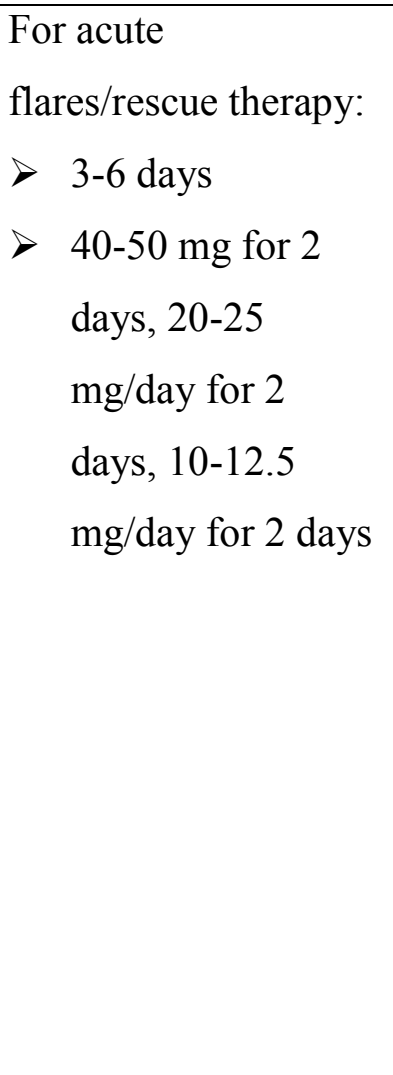 & $\begin{array}{l}\text { For late onset atopic } \\
\text { dermatitis in the } \\
\text { elderly: } \\
>>1 \text { year } \\
>5-10 \mathrm{mg} / \text { day }\end{array}$ & $\begin{array}{l}\text { Can be combined } \\
\text { with all other } \\
\text { agents: } \\
><20 \mathrm{mg} / \text { day }\end{array}$ & $\begin{array}{l}<12 \text { weeks }- \text { nil } \\
\text { unless clinically } \\
\text { indicated } \\
>12 \text { weeks }-\mathrm{HbA1c} \text {, } \\
\text { blood pressure, } \\
\text { osteoporosis } \\
\text { screening }\end{array}$ \\
\hline Ciclosporin & $\begin{array}{l}\text { Bridging to methotrexate, } \\
\text { azathioprine or } \\
\text { mycophenolate: } \\
>1-3 \text { months }\end{array}$ & $\begin{array}{l}>1-3 \mathrm{months} \\
>3-5 \mathrm{mg} / \mathrm{kg} / \text { day } \\
\text { May be used } \\
\text { intermittently for long }\end{array}$ & - & $\begin{array}{l}\text { Add to } \\
\text { methotrexate or } \\
\text { azathioprine: } \\
>1-3 \mathrm{mg}\end{array}$ & $\begin{array}{l}\text { Initially monthly } \\
\text { blood pressure, } \\
\text { fbc/renal/liver, then } \\
\text { 2-4 monthly }\end{array}$ \\
\hline
\end{tabular}




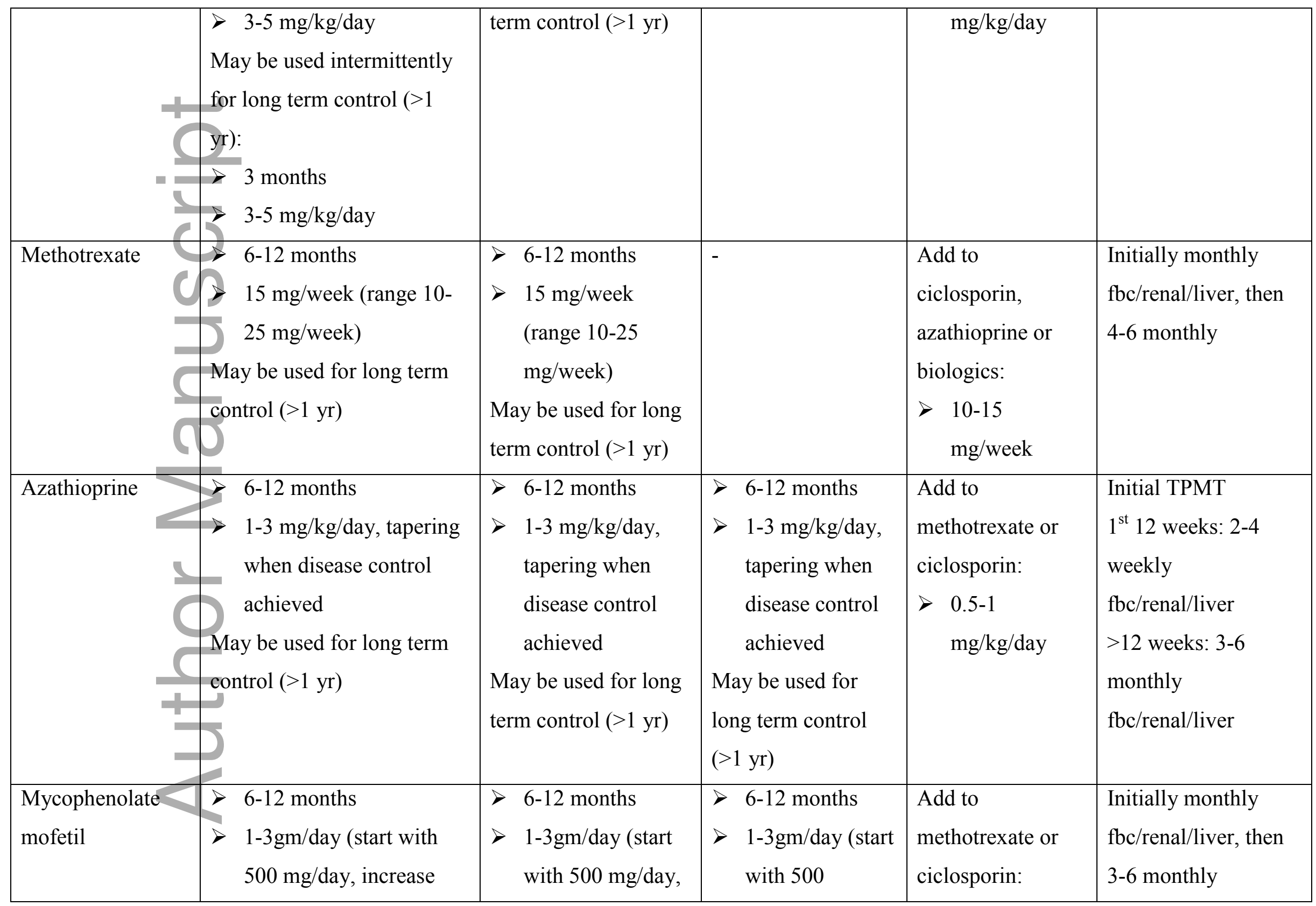

This article is protected by copyright. All rights reserved 


\begin{tabular}{|c|c|c|c|c|c|}
\hline & $\begin{array}{l}\text { weekly) } \\
\text { May be used for long term } \\
\text { control ( }>1 \mathrm{yr})\end{array}$ & $\begin{array}{l}\text { increase weekly) } \\
\text { May be used for long } \\
\text { term control (>1 yr) }\end{array}$ & $\begin{array}{l}\text { mg/day, } \\
\text { increase weekly) } \\
\text { May be used for } \\
\text { long term control } \\
(>1 \mathrm{yr})\end{array}$ & $>1 \mathrm{gm} / \mathrm{day}$ & \\
\hline $\begin{array}{l}\text { Anti- } \\
\text { Staphylococcus } \\
\text { antibiotics }\end{array}$ & $\begin{array}{l}\text { Acute infection: } \\
\text { Flucloxacillin } 500 \mathrm{~g} \text { tid for } \\
\text { 3-7 days }\end{array}$ & $\begin{array}{l}\text { Long term atopic } \\
\text { dermatitis control: } \\
\text { Flucloxacillin } 500 \mathrm{~g} \\
\text { bd with food for } 2-3 \\
\text { months }\end{array}$ & - & - & $\begin{array}{l}\text { Skin swabs for } \\
\text { sensitivities }\end{array}$ \\
\hline Alitretinoin & & $\begin{array}{l}\text { Cost may restrict to } \\
3^{\text {rd }} \text { line }\end{array}$ & $\begin{array}{l}\text { With significant } \\
\text { hand dermatitis: } \\
>6-12 \text { months } \\
>10-30 \mathrm{mg} / \text { day }\end{array}$ & $\begin{array}{l}\text { Add to } \\
\text { methotrexate or } \\
\text { azathioprine: } \\
>10 \mathrm{mg} / \text { day }\end{array}$ & \\
\hline Dupilumab & J & $\begin{array}{l}\text { Cost may restrict to } \\
3^{\text {rd }} \text { line }\end{array}$ & $\begin{array}{l}\text { After failure of } \\
\text { standard systemic } \\
\text { therapies: } \\
>\quad 6-24 \text { months } \\
>\quad 300 \mathrm{mg} \text { sc every } \\
\quad 2 \text { weeks }\end{array}$ & - & \\
\hline IVIg & - & - & $\begin{array}{l}\text { Various dosages: } \\
>3-6 \text { months } \\
>2 \mathrm{gm} / \mathrm{kg} / \mathrm{month}\end{array}$ & - & $\begin{array}{l}\text { Nil, unless clinically } \\
\text { indicated }\end{array}$ \\
\hline
\end{tabular}

This article is protected by copyright. All rights reserved 


\begin{tabular}{|c|c|c|c|c|c|}
\hline 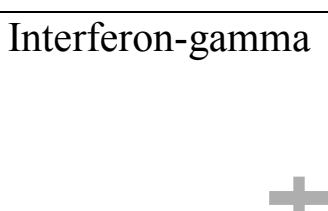 & - & - & $\begin{aligned}> & 3-6 \mathrm{months} \\
> & 50 \mu \mathrm{g} / \mathrm{m}^{2} 3 \\
& \text { times } / \text { week }\end{aligned}$ & - & $\begin{array}{l}\text { Initially monthly } \\
\text { fbc/renal/liver }\end{array}$ \\
\hline Tacrolimus & - & - & $\begin{aligned} &> 3-6 \text { months } \\
& \text { dosage } \\
& \text { dependent on } \\
& \text { formulation } \\
& \text { (narrow } \\
& \text { therapeutic } \\
& \text { window) }\end{aligned}$ & $\begin{array}{l}\text { Add to } \\
\text { methotrexate or } \\
\text { azathioprine: } \\
\text { dosage dependent } \\
\text { on formulation }\end{array}$ & $\begin{array}{l}\text { Initially monthly } \\
\text { blood pressure, } \\
\text { fbc/renal/liver, then } \\
\text { 2-4 monthly }\end{array}$ \\
\hline Montelukast & 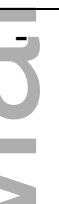 & - & $\begin{array}{l}3-6 \mathrm{month} \\
10 \mathrm{mg} / \text { day }\end{array}$ & $\begin{array}{l}\text { Add to } \\
\text { methotrexate or } \\
\text { ciclosporin }\end{array}$ & $\begin{array}{l}\text { Nil, unless clinically } \\
\text { indicated }\end{array}$ \\
\hline Vitamin D & - & - & - & $\begin{array}{l}\text { Add to all other } \\
\text { agents: } \\
>\quad 600-700 \\
\text { IU/day }\end{array}$ & 6 monthly calcium \\
\hline Leflunomide & 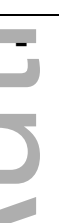 & - & - & $\begin{array}{l}\text { Little evidence of } \\
\text { benefit: } \\
>10-20 \mathrm{mg} / \text { day }\end{array}$ & $\begin{array}{l}\text { Initially monthly } \\
\text { fbc/renal/liver, then } \\
\text { 3-4 monthly }\end{array}$ \\
\hline Omalizumab & - & - & - & $\begin{array}{l}\text { Little evidence of } \\
\text { benefit. } \\
\text { May be of benefit }\end{array}$ & \\
\hline
\end{tabular}

This article is protected by copyright. All rights reserved 


\begin{tabular}{|c|c|c|c|}
\hline Ju & & & $\begin{array}{l}\text { if also has } \\
\text { significant chronic } \\
\text { urticaria }\end{array}$ \\
\hline $\begin{array}{l}\text { Other biologics: } \\
\text { IL-5 } \\
\text { IL12/23 } \\
\text { IL-13 } \\
\text { IL-31 } \\
\text { Anti-TNFs } \\
\text { Anti-CD20 } \\
\text { Anti-TSLP }\end{array}$ & $\begin{array}{l}\text { Cost may restrict to } \\
3^{\text {rd }} \text { line }\end{array}$ & $\begin{array}{l}\text { Data still too } \\
\text { immature to } \\
\text { determine place in } \\
\text { management }\end{array}$ & - \\
\hline $\begin{array}{l}\text { JAK inhibitors: } \\
\text { tofacitinib, } \\
\text { baricitinib and } \\
\text { upadacitinib }\end{array}$ & $\begin{array}{l}\text { Cost may restrict to } \\
3^{\text {rd }} \text { line }\end{array}$ & $\begin{array}{l}\text { Data still too } \\
\text { immature to } \\
\text { determine place in } \\
\text { management }\end{array}$ & - \\
\hline $\begin{array}{ll}1 \\
+\end{array}$ & $\begin{array}{l}\text { Cost may restrict to } \\
3^{\text {rd }} \text { line }\end{array}$ & $\begin{array}{l}>3-12 \text { month } \\
>\text { Titrate up to } 30 \\
\text { mg twice daily }\end{array}$ & - \\
\hline
\end{tabular}

This article is protected by copyright. All rights reserved 


\section{University Library}

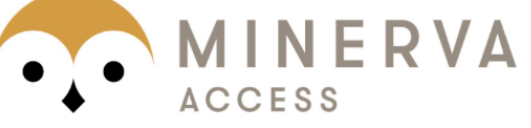

A gateway to Melbourne's research publications

Minerva Access is the Institutional Repository of The University of Melbourne

Author/s:

Rademaker, M;Agnew, K;Andrews, M;Baker, C;Foley, P;Gebauer, K;Gupta, M;Rubel, DM;Somerville, C;Sullivan, J;Wong, L-C

Title:

Managing atopic dermatitis with systemic therapies in adults and adolescents: An Australian/New Zealand narrative

Date:

2019-09-16

Citation:

Rademaker, M., Agnew, K., Andrews, M., Baker, C., Foley, P., Gebauer, K., Gupta, M., Rubel, D. M., Somerville, C., Sullivan, J. \& Wong, L. -C. (2019). Managing atopic dermatitis with systemic therapies in adults and adolescents: An Australian/New Zealand narrative. AUSTRALASIAN JOURNAL OF DERMATOLOGY, 61 (1), pp.9-22. https://doi.org/10.1111/ ajd.13141.

Persistent Link:

http://hdl.handle.net/11343/286425 